\title{
Beta vulgaris root extracts: as free radical scavengers and antibacterial agent
}

\author{
MARIYA SAANI ${ }^{1 *}$ and REENA LAWRENCE ${ }^{2}$ \\ 'Department of Chemistry, Sam Higginbottom University of Agriculture, \\ Technology and Sciences (Formerly AAI-DU), Prayagraj, India-211007. \\ ${ }^{2}$ Department of Biochemistry and Biochemical Engineering, Sam Higginbottom University \\ of Agriculture, Technology and Sciences (Formerly AAI-DU), Prayagraj, India-211007. \\ ${ }^{*}$ Corresponding author E-mail: mariya.saani@gmail.com \\ http://dx.doi.org/10.13005/ojc/360419
}

(Received: June 30, 2020; Accepted: August 22, 2020)

\begin{abstract}
In this work, Beta vulgaris root was examined for their natural pigments, antioxidant and antibacterial activities. Beta vulgaris root was extracted with methanol and ethanol solvents. Now these extracts were subjected to the determination of antioxidant potential using two different methods. Methanol extract showed maximum reducing power at $1.0 \mathrm{mg} / \mathrm{mL}$ followed by ethanol extract in reducing power assay and had highest $\beta$-carotene bleaching activity (33\%) than ethanol extract $(28 \%)$ in $\beta$-carotene method. Furthermore, antibacterial potential was carried out against four strains of bacteria two Gram-negative, E. coli, S. dysenteriae and two Garm-positive, B. subtilis and $S$. aureus at different concentration $(0.5,1.0,1.5$ and $2.0 \mathrm{mg} / \mathrm{mL})$. The result shows that methanol extract exhibited highest zone of inhibition $20 \pm 0.9 \mathrm{~mm}$ for $B$. subtilis followed by ethanol extract with $18.2 \pm 0.02 \mathrm{~mm}$ with MIC value $(111 \mu \mathrm{g} / \mathrm{mL})$ comparable with the standard Ampicillin. In addition to this, from the methanol extract ferulic acid was isolated and characterized via chromatographic and spectroscopic techniques. So that Beta vulgaris root extracts with their active natural pigments are optimistically taken in account as natural antioxidant and antibacterial agent.
\end{abstract}

Keywords: Beta vulgaris, Root extracts, Antioxidant, Antibacterial, Ferulic acid.

INTRODUCTION

Natural products from plants and their different parts occupy a significant place in consumer notice and are important in healthcare in most developing countries. In recent scenario, there is an increasing interest from the medicinal and scientific societies in giving them a place in evidence-based alternative medicine.
Interest in naturally occurring plant pigments, their therapeutic potential against human pathogens and ability to scavenge the free radical species as antioxidant agents have been increased day by day. Several studies have been conducted to evaluate the association between the active compounds present in plants and their antioxidant abilities ${ }^{1}$. Plants produced different natural pigments (e g., carotenoids, terpenoids, flavonoids, alkaloids, anthocyanins, betalains and phenolic compounds)

This is an Open Access article licensed under a Creative Commons license: Attribution 4.0 International (CC- BY). Published by Oriental Scientific Publishing Company @ 2018

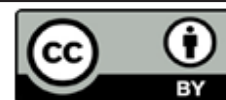


as antioxidant agents. They can avert or inactivates the oxidative damages produced by free radical species. Drugs derived from natural pigments have made effective contribution to human health. Therefore, natural pigments from resourceful plants should be investigated to obtain a valuable knowledge about their antioxidant, antimicrobial and other therapeutic properties.

Beta vulgaris (Beet root) is a member of Chenopodiaceae family (Fig. 1). It is a small sized plant also called as "Banjer" and originally located in South Europe as an erect annual or biennial herb with tuberous root stocks. Beta vulgaris is extensively cultivated in Europe, Russia, America, and Asia. Plant and root of Beta vulgaris have been used for so many years as a natural coloring agent in dairy and cookeries. The plenty of testimonials has been recommended that it's not only used as a harmless natural food color but also plays a chief role in discount of oxidative stress as of its free radical scavenging ability. This plant has high portion of sugar like glucose, glucuronic acid or apiose. Furthermore, Beta vulgaris also contains different phytochemicals includes phenolic acids, carotenoids, folic acids, flavonoids and minerals. It has been considered as one of the most health beneficial vegetables because of its remarkable antioxidant potential and great application in food industries due to account of red-violet betalain pigment $^{2,3}$. This plant is worthwhile in the treatment of wide variety of ailments including immune system stimulation, liver and kidney diseases. Beta vulgaris is potentially believed to be associated with antioxidant, anti-inflammatory, antimicrobial, hepato-protective activities ${ }^{4-8}$. Therefore, objectives of our study were examination of a) free radical scavenging activity b) antibacterial activity and c) Isolation \& identification of natural pigments by chromatographic techniques of Beta vulgaris root extracts.

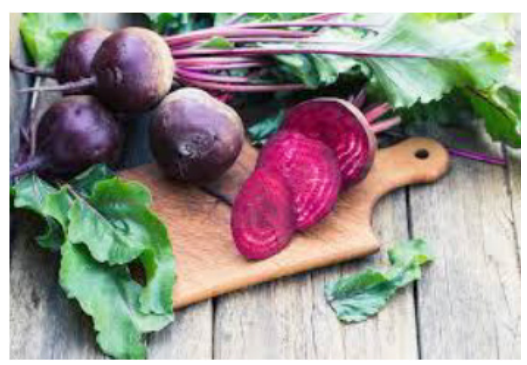

Fig. 1. Plant of Beta vulgaris

\section{MATERIALS AND METHODS}

\section{Material from Beta vulgaris}

Beta vulgaris roots were supplied by the Horticulture Department of SHUATS, Prayagraj. Roots were washed and cut into small pieces. The roots were shed dried and subjected to grinded powdered form.

\section{Plant extracts preparation}

The $60 \mathrm{~g}$ of root powder was extracted using two organic solvents, ethanol and methanol in soxhlet apparatus for 48 hours. The process was repeated twice with every solvent for better extraction. The extracts were concentrated to small volume by using rotary evaporator then concentrated to dryness and kept at $4^{\circ} \mathrm{C}$ before used.

\section{Free radical scavenging (antioxidant) activity By reducing power method}

The method of Huda-Faujan et al., ${ }^{9}$ has been used for determination of reducing power of the extracts. According to this assay, $2.5 \mathrm{~mL}$ of $\mathrm{K}_{3}[\mathrm{Fe}$ $\left.(\mathrm{CN})_{6}\right] 1 \%(\mathrm{w} / \mathrm{v})$ and phosphate Buffer (0.2 M, pH 6.6) of each were added to the variable concentrations $(0.0625,0.125,0.25,0.5,1.0 \mathrm{mg} / \mathrm{mL})$ of plant extracts and then added $1 \mathrm{~mL}$ of distilled water. The sample mixtures were kept in incubator for some time (20 min) at $50^{\circ} \mathrm{C}$. After that trichloroacetic acid $10 \%(\mathrm{w} / \mathrm{v}) 2.5$ $\mathrm{mL}$ was added in it then subjected to centrifugation (10 $\mathrm{min}$ at $3000 \mathrm{rpm})$. Ferric chloride $0.1 \%(\mathrm{w} / \mathrm{v})$ of $0.5 \mathrm{~mL}$ was added to the upper layer $(2.5 \mathrm{~mL})$ of sample solution before the absorbance was taken at $700 \mathrm{~nm}$ alongside a blank. Similar procedure was applied with Butylated hydroxytoluene (BHT) (conc. 0.0625, 0.125, 0.25, 0.5, $1 \mathrm{mg} / \mathrm{mL}$ ) which was used as standard reference. An increasing absorbance was an indicator of an increased reducing ability of the sample mixture.

\section{$\beta$-carotene bleaching method ${ }^{10}$}

In this method, $0.02 \mathrm{mg}$ crystalline $\beta$-carotene was disbanded in chloroform $(10 \mathrm{~mL})$ after that, added $200 \mathrm{mg}$ of (Merck) tween-80 reagent and linoleic acid (20 mg). Rotary evaporator was used to evaporate the chloroform at $40^{\circ} \mathrm{C}$ till $5 \mathrm{~min}$, followed by the addition of distilled water about $50 \mathrm{~mL}$ with vigorous stirring until an emulsion was formed. This emulsion ( $5 \mathrm{~mL}$ ) was mixed into $0.1 \mathrm{~mL}$ each of two extracts. BHT was used as reference. The sample and reference solutions were incubated 
under $50^{\circ} \mathrm{C}$. After every 20 min readings were taken for two hours at 470 nano-meters.

(\%) Inhibition= (Absorbance after two $\mathrm{h}$ of assay/ Initial absorbance) $\times 100$

\section{Antibacterial activity}

The bacterial strains tested in this work including Gram-positive, Staphylococcus aureus (MCCB 0045), Bacillus subtilis (MCCB 0142) and Gram-negative, Escherichia coli (MCCB 0016), Shigella dysenteriae (MCCB 0042), were collected from the Microbial culture collection bank of Microbiology and Fermentation Technology, Sam Higginbottom University of Agriculture, Technology and Sciences (SHUATS), Prayagraj.

\section{Agar well diffusion method}

Antibacterial activity was examined against four bacterial strains (two Gram-positive and two Gram-negative $)^{11}$. Petri-plates were prepared by pouring $15 \mathrm{~mL}$ of nutrient agar medium (N.A.) in it, after that $10 \mathrm{~mL}$ of microbial cultural broth was added in each with even distribution. Wells ( $5 \mathrm{~mm}$ size) were made with the help of sterile borer. Plant extracts $(20 \mu \mathrm{l})$ of different concentration $(0.5,1.0,1.5,2.0$ $\mathrm{mg} / \mathrm{mL}$ ) were poured in these wells. Ampicillin of 10 $\mathrm{mg} / \mathrm{mL}$ was taken as positive control. Petri-plates were incubated under $37^{\circ}$ for 24 hours. After that, petri-plates were checked for zone of inhibition (ZI) around each well and measured in millimeters. If zone of inhibition was appeared within the range of 4-6 $\mathrm{mm}$ considered to be effective. However, if ZI was recorded with 6-9 $\mathrm{mm}$ size might be active and zone larger than $9 \mathrm{~mm}$ was very active ${ }^{12}$.

\section{Minimum Inhibitory Concentration (MIC) assay}

Initial minimum inhibitory concentration (MIC) assay was applied as given by Andrews $^{13}$, Rasooli and Abyanek ${ }^{14}$. MIC of the plant extracts of Beta vulgaris was evaluated by preparing the dilution of the plant extracts in decreasing order. Dilution of the extract was made in sterile broth medium, ranging from $1000 \mu \mathrm{g} / \mathrm{mL}$ to $12 \mu \mathrm{g} / \mathrm{mL}$ in test-tubes labeled 1 to 5 . For every dilution standardized bacterial inoculums about $10 \mu \mathrm{l}$ was poured with (108-109) colony-forming unit/mL. The cultural tubes were incubated under $37^{\circ} \mathrm{C}$ for 24 hours. A set of cultural tubes devoid of plant extract was considered as control. The lowermost concentration of plant extract which prevent the microorganism growth founded by the absence of turbidity, was considered as initial minimum inhibitory concentration (MIC) of the sample plant extract. A loop of $10 \mu$ from each cultural tube was streaked on nutrient agar plates. After incubation under $37^{\circ} \mathrm{C}$ for $24 \mathrm{~h}$, sample lowest concentration without any noticeable growth was checked and considered as MIC of plant extract.

\section{Isolation \& characterization of compounds from plants extracts}

The compounds present in Beta vulgaris roots extracts were isolated by the application of the column chromatography. In this method the plant extract to be analyzed was applied to the top of the column by making slurry. The mobile phase (liquid solvent) was eluted throughout the column. The separation of different compounds was done by the establishment of equilibrium between the compound absorbed on solid phase and the eluting solvent as a liquid phase flowing down to the column. The separated compounds were separated with the eluting solvent that dripped out from the column at $1 \mathrm{~mL} / \mathrm{min}$ flow rate.

The isolation or purification of the natural compounds present in the crude methanol extract of Beta vulgaris roots $(1.5 \mathrm{~g})$ was performed by using column chromatographic technique. Silica gel (Merck with 60-120 mesh size) was used as a stationary phase and different ratio of chloroform: methanol $(95: 5 ; 90: 10 ; 85: 15 ; 80: 20)$ was used as a liquid mobile phase. Fractions 150 in number of $100 \mathrm{~mL}$ volume each were collected from this column. Purity and composition of the fractions were determined by the $R_{f}$-values of the isolated compounds with the help of thin layer chromatography (TLC) technique. The isolated compounds were characterized by spectroscopic technique like IR, ${ }^{1} \mathrm{HNMR}$ and mass spectroscopic techniques respectively. Infrared spectra were performed on a PerkinElmer Spectrum Version 10.03.06 (PEService 63) FT-IR spectrophotometer. Only notable IR absorptions $\left(\mathrm{cm}^{-1}\right)$ are listed. Proton NMR spectra were recorded on Aglinant-700-vnmrs 700 NMR spectrometer operating at $300 \mathrm{M} \mathrm{Hz}$ for ${ }^{1} \mathrm{H}-\mathrm{NMR}$ measurement. The chemical shift is described as parts per million (ppm) units towards TMS. Liquid $\mathrm{CDCl}_{3}$ was taken as solvent. High resolution mass spectra (HRMS) were detailed with a JEOL-AccuTOF JMS-T100LC mass spectrometer devising a direct analysis in real time source (DART). The test samples were exposed 
as such in anterior of DART source. Helium (Dry) in 4 LPM flow rate was used for ionization at $350^{\circ} \mathrm{C}$. The outlet was fixed at $28 \mathrm{~V}$ for the collection of spectrum.

\section{Statistical analysis}

The data recorded during the course of investigation was subjected to statistical analysis by "Analysis of variance technique" (Fisher and Yates, 1968). The significant and non-significant treatment effects were judged with the help of "F" (variance ratio) table. The significant differences between the means were tested against the critical difference at $5 \%$ probability level.

\section{RESULTS AND DISCUSSION}

\section{Antioxidant activity Reducing power activity}

In this spectrophotometric method the antioxidant power of sample solution was studied by the appearance of yellow to different shades of blue and green colour, which was happened because of the reduction of ferric ions into ferrous ions. The antioxidant activity of plant extract had been measured by reduction of ferric-cyanide ion ( $\mathrm{Fe}^{3+}$ form) into ferro-cyanide ion $\left(\mathrm{Fe}^{2+}\right)$ present in sample solution. This ferro-cyanide ion $\left(\mathrm{Fe}^{2+}\right)$ react with alcoholic ferric chloride and produced ferricferrocyanide (Prussian blue) pigment, which might be absorbed at $700 \mathrm{~nm}$. Increasing absorbance was an indicator of increased reducing ability of sample plant extract.

The reducing potential of two different extracts of Beta vulgaris root was determined. Reducing power of test samples was found significant as compared to the standard BHT. As shown in (Table 1) increased the extract concentration (0.062, $0.125,0.25,0.5$ and $1.0 \mathrm{mg} / \mathrm{mL}$ ), the absorbance of test samples was also increased gradually. According to the result the reducing power of Beta vulgaris roots extracts was found significant as methanol extract at $1.0 \mathrm{mg} / \mathrm{mL}$ concentration showed maximum reducing power $(0.688 \pm 0.004)$ followed by ethanol extract $(0.48 \pm 0.025)$ as compared to BHT $(1.44 \pm 0.043)$. The methanol extract at $0.5 \mathrm{mg} / \mathrm{ml}$, showed significant reducing power $(0.455 \pm 0.005)$ than ethanol extract $(0.394 \pm 0.06)$ contrast to BHT (1.343 \pm 0.044$)$. Likewise, at 0.25 $\mathrm{mg} / \mathrm{mL}$ concentration, methanol, ethanol extract and $\mathrm{BHT}$ showed significant reducing power as $(0.392 \pm 0.021),(0.307 \pm 0.005)$ and $(1.286 \pm 0.010)$ respectively. Greater reducing power $(0.270 \pm 0.062)$ was observed for methanol extract followed by ethanol extract $(0.289 \pm 0.004)$ as compared to $\mathrm{BHT}(1.126 \pm 0.006)$ at $0.125 \mathrm{mg} / \mathrm{mL}$ concentration. At $0.062 \mathrm{mg} / \mathrm{mL}$ concentration, methanol extract exhibited higher reducing power of $(0.222 \pm 0.012)$ than ethanol extract $(0.195 \pm 0.005)$ as compared to BHT $(0.84 \pm 0.048)$. This result was in line with the study conducted by Canadanovic- Brunet stated that as we increased the extract concentration, the absorbance of test samples was also increased gradually ${ }^{15}$. Antioxidant activity in reducing power assay is as follows: - BHT > methanol > ethanol. The effect of test samples (plant extracts) and concentrations on antioxidant activity was found to be statistically significant (Fcal 147.46> Ftab 4.46 due to samples) and non-statistically significant (Fcal 11.61> Ftab 3.84 due to concentrations) at $5 \%$ level of significance.

The data obtained from this method, showed that all the samples increased their reducing ability when the concentration of extracts was increased. It was clearly indicating that from the (Table 1) all the concentrations of methanol extract of the Beta vulgaris root exhibited significant amount of reductive ability but as compared to that of ethanol extract and standard butylated hydroxytoluene.

Table 1: Reducing power activity of Beta vulgaris roots extracts and standards (BHT)

\begin{tabular}{ccccc}
\hline Extract Concentrations $(\mathrm{mg} / \mathrm{mL})$ & \multicolumn{3}{c}{ The absorbance in $700 \mathrm{~nm}$ of Beta vulgaris root extract } \\
& $0.0625(\mathrm{mg} / \mathrm{mL})$ & $0.125(\mathrm{mg} / \mathrm{mL})$ & $0.25(\mathrm{mg} / \mathrm{mL})$ & $0.5(\mathrm{mg} / \mathrm{mL})$ \\
\hline Ethanol & $0.195 \pm 0.005$ & $0.289 \pm 0.004$ & $0.307 \pm 0.005$ & $0.394 \pm 0.060$ \\
Methanol & $0.222 \pm 0.012$ & $0.270 \pm 0.062$ & $0.392 \pm 0.021$ & $0.455 \pm 0.005$ \\
BHT & $0.64 \pm 0.048$ & $1.126 \pm 0.006$ & $1.286 \pm 0.010$ & $1.343 \pm 0.044$ \\
\hline
\end{tabular}

Values were expressed in Mean S.D. $(n=3)$ 


\section{$\beta$-carotene bleaching method}

This method studied the antioxidant power of the plant extracts that scavenged the linoleic acid peroxide radicals. These radicals may cause the oxidation of the $\beta$-carotene molecules present in the test solution. After the oxidation, $\beta$-carotene losses its orange colour and go through a quick decolourization ${ }^{16}$.

Anti-decolorizing potential of each test solution was examined by observing the colour changing frequency of test sample emulsion until two hours after every $20 \mathrm{~min}$ at $470 \mathrm{~nm}$. Each test sample and standard BHT was taken 1mg/ $\mathrm{mL}$ in concentration. From this analysis (Table 2), methanol extract of Beta vulgaris root in the first 20 min showed $(1.46 \pm 0.041)$ optical density followed by ethanol extract $(1.30 \pm 0.02)$ as compared to $(1.63 \pm 0.02)$ shown by the BHT. In first hour of inhibition, optical density decreased to $(1.31 \pm 0.020)$ for methanol extract, $(1.18 \pm 0.172)$ for ethanol extract as compared to $(1.45 \pm 0.02)$ shown by the BHT. During the second hour, it came to $(1.07 \pm 0.090)$ for methanol extract, $(1.0 \pm 0.152)$ for ethanol extract as compared to $(1.20 \pm 0.02)$ shown by the BHT. These reading suggest that the samples act as significant antioxidants. Methanol extract of Beta vulgaris root had highest $\beta$-carotene bleaching activity (33\%) than ethanol extract but less than that of standard (BHT). The decreasing order exhibited by these extracts and standard BHT (43.8\%)> methanol $(33 \%)>$ ethanol $(28 \%)$. The effect of test samples (extracts) and time interval on antioxidant activity was found to be statistically significant (Fcal 261.65> Ftab 3.86 due to samples) and nonstatistically significant (Fcal 4.42> Ftab 3.86 due to time interval) at $5 \%$ level of significance.

Table 2: $\beta$-Carotene bleaching activity of Beta vulgaris roots extracts and BHT

\begin{tabular}{cccc}
\hline Time interval & \multicolumn{3}{c}{$\begin{array}{c}\text { The absorbance in } 470 \mathrm{~nm} \text { of } \\
\text { Beta vulgaris root extracts }\end{array}$} \\
\hline & $\begin{array}{c}\text { Ethanol extract } \\
(1 \mathrm{mg} / \mathrm{mL})\end{array}$ & $\begin{array}{c}\text { Methanol extract } \\
(1 \mathrm{mg} / \mathrm{mL})\end{array}$ & $\begin{array}{c}\mathrm{BHT} \\
(1 \mathrm{mg} / \mathrm{mL})\end{array}$ \\
\hline 0 min & $1.67 \pm 0.147$ & $1.67 \pm 0.147$ & $1.67 \pm 0.147$ \\
$20 \mathrm{~min}$ & $1.30 \pm 0.02$ & $1.46 \pm 0.041$ & $1.63 \pm 0.02$ \\
$40 \mathrm{~min}$ & $1.23 \pm 0.151$ & $1.41 \pm 0.080$ & $1.56 \pm 0.02$ \\
$60 \mathrm{~min}$ & $1.18 \pm 0.172$ & $1.31 \pm 0.020$ & $1.45 \pm 0.02$ \\
$80 \mathrm{~min}$ & $1.07 \pm 0.164$ & $1.24 \pm 0.04$ & $1.36 \pm 0.02$ \\
$100 \mathrm{~min}$ & $1.04 \pm 0.147$ & $1.11 \pm 0.087$ & $1.28 \pm 0.02$ \\
$120 \mathrm{~min}$ & $1.01 \pm 0.152$ & $1.07 \pm 0.090$ & $1.20 \pm 0.02$ \\
(\%)Inhibition & $28 \%$ & $33 \%$ & $43.8 \%$ \\
\hline Values were expressed in Mean S.D. $(\mathrm{n}=3)$ &
\end{tabular}

\section{Antibacterial activity}

\section{Agar well diffusion method}

Antibacterial power of test sample was taken in account if zone of inhibition ( $\mathrm{ZI}$ ) appeared within the range of 4-6 mm considered to be effective. However, if $\mathrm{Zl}$ was recorded with 6-9 $\mathrm{mm}$ size might be active and zone larger than $9 \mathrm{~mm}$ was very active ${ }^{12}$.

Agar well diffusion method was applied here to examine the antibacterial effect of methanol and ethanol root extract of Beta vulgaris. Four strains of bacteria (two Gram-negative, E. coli, S. dysenteriae, and two Garm-positive, B. subtilis and S. aureus) were screened alongside with ampicillin and DMSO as standard antibiotic and control respectively. Both the extract showed significant activity against selected bacterial strains at different concentration $(0.5,1.0,1.5$ and $2.0 \mathrm{mg} / \mathrm{mL})$. Methanol and ethanol extracts possessed varied zone of inhibition within range from 10-20 $\mathrm{mm}$ and 9.6-18.2 $\mathrm{mm}$ separately (Table 3 \& 4). From this analysis, methanol extract exhibited highest zone of inhibition $20 \pm 0.9 \mathrm{~mm}$ in size for $B$. subtilis at $2.0 \mathrm{mg} / \mathrm{mL}$ concentration. Ethanol extract also showed maximum zone of inhibition at 2.0 $\mathrm{mg} / \mathrm{mL}$ concentration with $18.2 \pm 0.02 \mathrm{~mm}$ size against the same Gram-positive bacteria B. subtilis.

Table 3: Antibacterial activity of Beta vulgaris roots methanol extract

\begin{tabular}{ccccc}
\hline $\begin{array}{c}\text { Extract } \\
\begin{array}{c}\text { Concentration } \\
(\mathrm{mg} / \mathrm{mL})\end{array}\end{array}$ & E. coli & S. dysenteriae & S. aureus & Inhibition zone (mm) \\
& & Bgainst bacterial strains & \\
\hline 0.5 & $8.6 \pm 0.6$ & $8 \pm 0.15$ & $13 \pm 1.00$ & $15 \pm 1.20$ \\
1.0 & $10 \pm 0.20$ & $8.2 \pm 0.50$ & $15 \pm 1.32$ & $16.5 \pm 0.20$ \\
1.5 & $11 \pm 0.15$ & $9.7 \pm 0.30$ & $16 \pm 1.00$ & $18 \pm 0.90$ \\
2.0 & $12 \pm 0.15$ & $10 \pm 0.92$ & $17.6 \pm 0.52$ & $20 \pm 0.9$ \\
Std. Drug & 17.00 & 20.00 & 22.00 & 23.00 \\
$(2.0 \mathrm{mg} / \mathrm{mL})$ & & & & \\
Mean \pm S.D., $\mathrm{n}=3$ & & & & \\
\hline
\end{tabular}

Table 4: Antibacterial activity of Beta vulgaris roots ethanol extract

\begin{tabular}{ccccc}
\hline $\begin{array}{c}\text { Extract } \\
\begin{array}{c}\text { Concentration } \\
(\mathrm{mg} / \mathrm{mL})\end{array}\end{array}$ & E. coli & $\begin{array}{c}\text { Inhibition zone }(\mathrm{mm}) \\
\text { against bacterial strains }\end{array}$ \\
\hline 0.5 & $8.3 \pm 0.75$ & $7.2 \pm 0.25$ & $10 \pm 0.50$ & $13 \pm 0.70$ \\
1.0 & $9 \pm 2.0$ & $8.3 \pm 0.33$ & $11 \pm 0.60$ & $15 \pm 1.00$ \\
1.5 & $96 \pm 0.42$ & $9.0 \pm 0.90$ & $12 \pm 0.13$ & $16.3 \pm 0.85$ \\
2.0 & $10 \pm 0.15$ & $9.6 \pm 0.25$ & $13.2 \pm 0.26$ & $18.2 \pm 0.02$ \\
Std. Drug & 17.00 & & 22.00 & 23.00 \\
$(2.0 \mathrm{mg} / \mathrm{mL})$ & & & & \\
Mean \pm S.D., $\mathrm{n}=3$ & & & & \\
\hline
\end{tabular}


Our study on antibacterial activity show that both the extracts of Beta vulgaris roots are significantly active against Gram-positive bacteria and these results in line with the report of Kumar and Brooks ${ }^{17}$. Antibacterial activity of Beta vulgaris root extracts for selected bacterial strains was very much similar as to shown by antibiotic (ampicillin). The methanol and ethanol extracts of Beta vulgaris exhibited antibacterial activity in descending order B. subtilis $>S$. aureus $>E$. coli>S. dysenteriae. All bacteria tested in this study were multiple drug resistant bacteria. These results showed similar findings with Canadanovic-Brunet et al., antibacterial study on Beet root Pomace extract ${ }^{15}$. The antibacterial activity of Beta vulgaris root methanol extract found to be non-statistically significant (Fcal 212.80> Ftab 3.86 due to bacteria) and statistically significant (Fcal $31.457>$ Ftab 3.86 due to concentration) at $5 \%$ level of significance. The effect of bacteria and concentrations on the antibacterial activity of Beta vulgaris root ethanol extract found to be non-statistically significant (Fcal 168.774> Ftab 3.86 due to bacteria) and statistically significant (Fcal 23.821>Ftab 3.86 due to concentration) at $5 \%$ level of significance.

\section{Minimum inhibitory concentration of Beta vulgaris roots extracts}

The lower most concentration of sample extract that possessed its inhibition effect against a microorganism resulting in no prominent turbidity was noted as the MIC rate of test sample ${ }^{13,14}$. Different concentrations ranged from $4 \mu \mathrm{g} / \mathrm{mL}$ to $1000 \mu \mathrm{g} / \mathrm{mL}$ of Beta vulgaris roots extracts (methanol and ethanol), were prepared and the MIC values against selected bacterial strains (E. coli, S. aureus, B. subtilis and $S$. dysenteriae) were observed. The MIC values of Beta vulgaris root methanol, ethanol extracts for selected bacteria are shown in (Tables 5-6).

Table 5: MIC $(\mu \mathrm{g} / \mathrm{mL})$ value for Beta vulgaris methanol extract

\begin{tabular}{ccccc}
\hline $\begin{array}{c}\text { Extract } \\
\begin{array}{c}\text { Concentration } \\
(\mu \mathrm{g} / \mathrm{mL})\end{array}\end{array}$ & \multicolumn{5}{c}{ MIC value $(\mu \mathrm{g} / \mathrm{ml})$ for extract } \\
\hline 1000 & - & - & - & - \\
333 & $*$ & - & - & $*$ \\
111 & + & $*$ & $*$ & + \\
37 & + & + & + & + \\
12 & + & + & + & + \\
4 & + & + & + & + \\
MIC & 333 & 111 & 111 & 333 \\
\hline
\end{tabular}

(+) Growth, (*) MIC, (-) No Growth
Table 6: MIC $(\mu \mathrm{g} / \mathrm{mL})$ value for Beta vulgaris ethanol extract

\begin{tabular}{ccccc}
\hline $\begin{array}{c}\text { Extract } \\
\begin{array}{c}\text { Concentration } \\
(\mu \mathrm{g} / \mathrm{mL})\end{array}\end{array}$ & E. coli & $\begin{array}{c}\text { MIC value }(\mu \mathrm{g} / \mathrm{mL}) \text { for extract } \\
\text { against bacterial strains }\end{array}$ \\
\hline 1000 & - & - & - & - \\
333 & $*$ & $*$ & - & $*$ \\
111 & + & + & $*$ & + \\
37 & + & + & + & + \\
12 & + & + & + & + \\
4 & + & + & + & + \\
MIC & 333 & 333 & 111 & 333 \\
\hline
\end{tabular}

(+) Growth, (*) MIC, (-) No Growth

In order to determine bactericidal or bacteriostatic mode of action on the sensitive bacteria, the Beta vulgaris roots extracts were tested for MIC. The ability of extracts to inhibit the growth of tested bacterial strains in fresh culturing broth was observed. Methanol extract of Beta vulgaris roots showed significant activity against $B$. subtilis with MIC value $(111 \mu \mathrm{g} / \mathrm{mL})$. According to the result given in this work, methanol extract of Beta vulgaris exhibits strong activity against Gram-positive bacterial strains. On the other hand, ethanol extract showed weak antibacterial activity that was comparable with the standard.

Our results give the knowledge that the Beta vulgaris possessed significant activity towards Gram-positive bacterial strains. Chandrasekharan et al., ${ }^{18}$ have been studied antimicrobial activity and composition of fatty acid methyl ester extracts of four halophytic plants from Chenopodiaceae by GC-MS.

\section{Isolation and characterization of pigments from Beta vulgaris roots extracts}

Beta vulgaris is well known to produce a great variety of natural pigments and phenolic compounds ${ }^{19}$. Natural compounds were isolated from Beta vulgaris roots extracts by using column chromatography. Isolation of compounds from methanol extract $(1.5 \mathrm{~g})$ of Beta vulgaris roots was performed by column chromatographic technique. Silica gel about $100 \mathrm{~g}$ was used as stationary (solid) phase. There after 150 fractions collected of $100 \mathrm{~mL}$ each (Table 7). The solubility of isolated compounds was checked in polar, non-polar, protic, aprotic and inorganic solvents. It was observed that the isolated compounds were sparingly soluble in chloroform, hexane, benzene, water and dimethyl formamide (DMF), insoluble in xylene and carbon tetrachloride but completely soluble in ethanol, methanol, DMSO and acetone. The $\mathrm{R}_{\mathrm{f}}$-value via thin layer chromatography was used in the detection of particular isolated compounds. Silica gel-G was used as solid phase and organic solvent (e.g. hexane, chloroform, ethyl acetate, ethanol, and methanol) 
as mobile phase. Dried plates gave clear spots after exposing to iodine vapors and sprayed with alcoholic

ferric chloride with $R_{f}$-value: 0.74 (ChloroformMethanol $=85:$ 15).

Table 7: Separation of compound from methanol extract of Beta vulgaris roots, column chromatography

\begin{tabular}{|c|c|c|c|c|}
\hline Fraction no & Solvent system $(\mathrm{v} / \mathrm{v})$ & Spot on TLC & Weight of compound(mg) & Further investigation \\
\hline $1-10$ & Hexane & No spot & - & - \\
\hline $11-20$ & $\begin{array}{c}\text { Hexane-Chloroform } \\
(50 \cdot 50)\end{array}$ & No spot & - & \\
\hline $21-40$ & Chloroform & Streaking & - & - \\
\hline $41-60$ & $\begin{array}{c}\text { Chloroform-Methanol } \\
(95: 5)\end{array}$ & Streaking & & - \\
\hline $61-80$ & $\begin{array}{l}\text { Chloroform-Methanol } \\
(90: 10)\end{array}$ & Complex mixture & & \\
\hline $81-99$ & $\begin{array}{c}\text { Chloroform-Methanol } \\
(85: 15)\end{array}$ & Compound & $50 \mathrm{mg}$ & Investigated \\
\hline $100-120$ & $\begin{array}{l}\text { Chloroform-Methanol } \\
(80: 20)\end{array}$ & Streaking & & \\
\hline $121-135$ & $\begin{array}{l}\text { Chloroform-Methanol } \\
(70: 30)\end{array}$ & No spot & - & - \\
\hline $135-150$ & $\begin{array}{c}\text { Chloroform-Methanol } \\
(60: 40)\end{array}$ & Washing & - & - \\
\hline
\end{tabular}

The characterization of isolated compounds was done by IR, ${ }^{1} \mathrm{H}-\mathrm{NMR}$ and mass spectroscopic techniques. The functional groups in pure organic compounds were detected by the use of IR spectroscopy $\left(4000-600 \mathrm{~cm}^{-1}\right)$ techniques. The FT-IR spectrum (Fig. 2) of the compound showed a weak band at $2921 \mathrm{~cm}^{-1}$ was belongs to the vibration frequency for $=\mathrm{C}=\mathrm{H}$ group of benzene ring; the strong peak at $1514 \mathrm{~cm}^{-1}$ was appeared for $\mathrm{C}=\mathrm{C}$ group of benzene ring; and middle peak at 1215 $\mathrm{cm}^{-1}$ stretching vibration was recognized to $\mathrm{C}=\mathrm{OH}$ of phenol ${ }^{20}$. Furthermore, a solid peak at $1663 \mathrm{~cm}^{-1}$ stretching vibrations was establishes for carboxylic group, that was shifted to the lower side as 1700 $\mathrm{cm}^{-1}$ for carbonyl group. The ${ }^{1} \mathrm{H}-\mathrm{NMR}$ spectrum of compound (Fig. 3) display a db at $\delta 6.94(1 \mathrm{H}, \mathrm{d}$, $\mathrm{J}=8.1 \mathrm{~Hz}, \mathrm{H}-5) \delta 7.11(1 \mathrm{H}, \mathrm{d}, \mathrm{J}=8.2 \mathrm{~Hz}, \mathrm{H}-6)$ and $\delta$ $7.35(1 \mathrm{H}, \mathrm{dd}, \mathrm{J}=\mathrm{Hz}, \mathrm{H}-2)$ indicating H's of aromatic ring. It shows a strong peak at $\delta 8.64(\mathrm{~s},-\mathrm{COOH})$ which indicate the presence of carboxylic groups. methoxide group was also present and showed peak at $\delta 3.94\left(3 \mathrm{H}, \mathrm{s}, \mathrm{OCH}_{3}\right)$ at $\mathrm{C}-8$ position. $\mathrm{A}$ broad singlet was observed at $\delta 2.11$ (3H, bars) due to presence of methyl group ${ }^{21}$. As comprehended in mass-spectra (Fig. 4 \& 5), the mass weight was deliberate to be $194.18 \mathrm{~g} / \mathrm{mol}$ because the highest signal observed as $[\mathrm{M}+\mathrm{H}]^{+}=195 \mathrm{~m} / \mathrm{z}$. It was followed by the loss of $\left[\mathrm{CO}_{2}\right]^{+}$and $[\mathrm{OH}]^{+}$ion from $[\mathrm{M}+\mathrm{H}]^{+}$ion, gave $m / z=151$ and $m / z=177$ ion product. From the spectral analysis and also comparing the data with the data given in Li et al., ${ }^{22}$, Compound was identified as Ferulic acid (Figure 6).

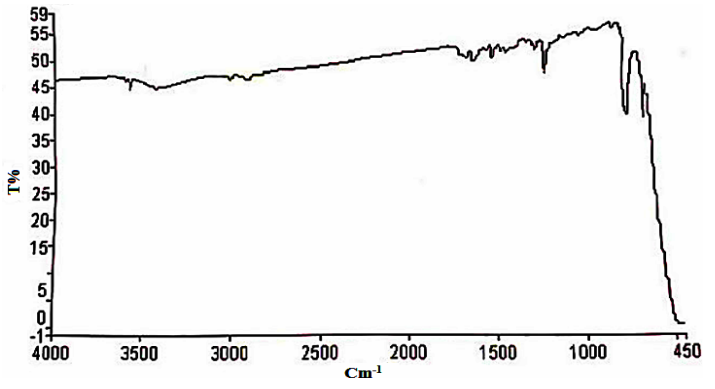

Fig. 2. IR-spectrum of compound (\%Transmittance vs. Wavenumber $\mathrm{cm}^{-1}$ )

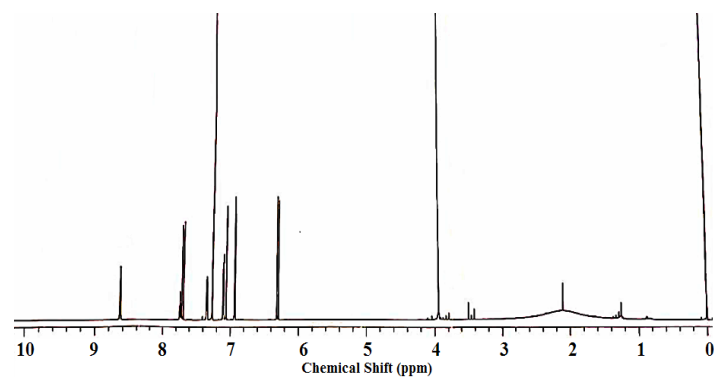

Fig. 3. Proton-NMR spectrum of compound (Intensity vs. Chemical shift (ppm)

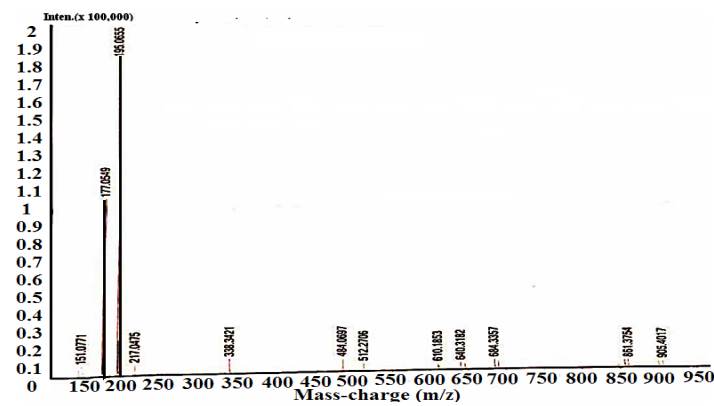

Fig. 4. ESI-MS spectrum of compound (Intensity vs. Mass -charge (m/z) 


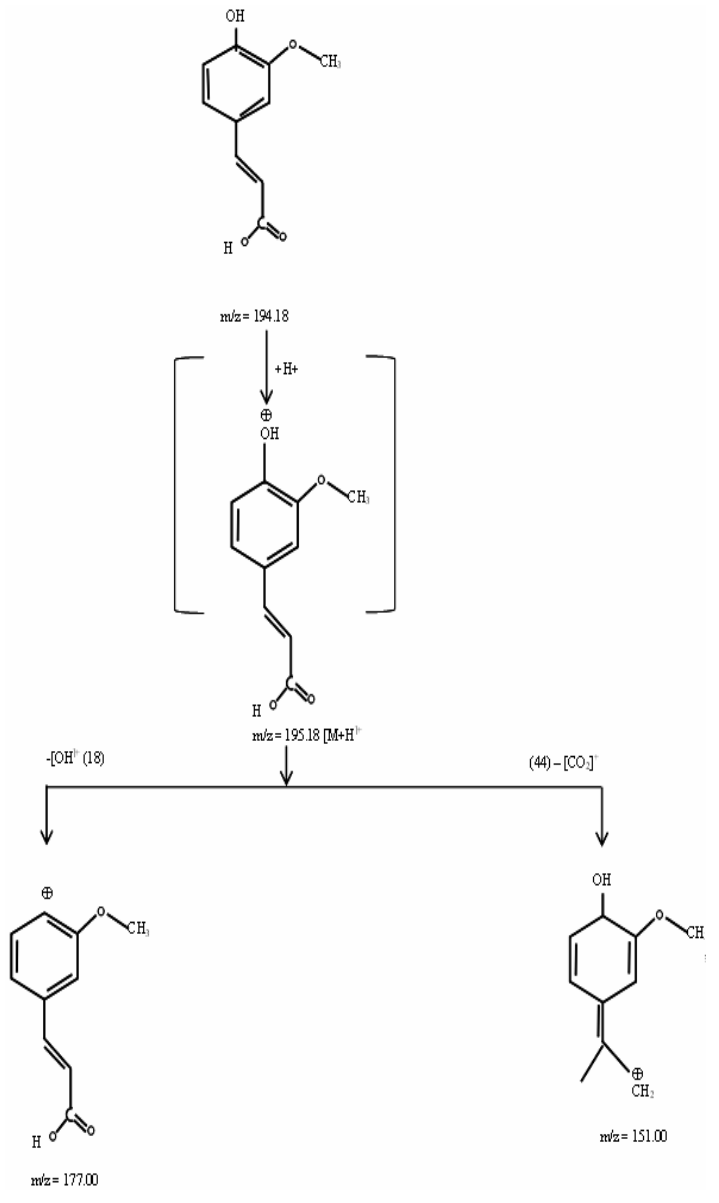

Fig. 5. Mass-fragmentation of compound<smiles>COc1cc(/C=C/C(=O)O)ccc1O</smiles>

Fig. 6. Ferulic acid

On the basis of present work, it is remarkable to establish that Beta vulgaris roots extracts possess different natural pigments mostly phenolic compounds like ferulic acid, which was isolated and characterized by chromatographic and spectrometric techniques. These extracts showed significant antioxidant activity and effective against Gram-positive bacterial strains. Therefore, Beta vulgaris root extracts are optimistically considered as an auspicious source of natural pigments for treatment of several health problems.

\section{ACKNOWLEDGEMENT}

I would like to give great thank towards my research guide, Dr. Reena Lawrence for their support and encouragement in research work.

\section{Conflict of interest}

There is no conflict of interest that can influence our work.

\section{REFERENCES}

1. Huda-Faujan, N.; Noriham, A.; Norrakish, A. S.; Babji, A. S. Antioxidative activity of water extract of some Malaysian herbs. Asian Food Journal., 2007, 14, 61-8.

2. Dlim, M. M.; Alsabri, S. G.; Mohamad, S. S.; Zetrini, A. E.; Salem, A. A. H.; and Auzi, A. A. Use of Beta vulgaris as natural colouring agent for food and cosmetics in Libya. Journal of Chemical and Pharmaceutical Research., 1994, 5, 340-5.

3. Koppenol, W. H. Free radical damage and its control. Elsevier Science Publication Company. Inc. New York., 1994, 3-24.

4. Chakole, R.; Zade, S.; Charde, M. Antioxidant and anti-inflammatory activity of ethanolic extract of Beta vulgaris linn root. Internatioal Journal of Biomedical Advance and Research., 2011, 2, 124-30.

5. Kapur, A.; Sati, S.; Ranjan, A.; Gupta, P.
Screening methanolic extract of Beta vulgaris roots for photoprotective activity. International Journal of Pharmacy and Pharmaceutical Sciences., 2012, 4,124-7.

6. Kim, I.; Chrin, Y. W.; Lim, S. W.; Kim, Y. C.; Kim, J. Norisoprenoids and Hepatoprotective flavone glycosides from the aerial parts of Beta vulgaris. Archives of Pharmacal Research., 2004, 27, 600-3.

7. Koubaier, H. B. H.; Essaidi, I.; Snoussi, A.; Zyoulli, S.; Chaabouni, M. M.; Thonart, P. Effect of Saccharomyces cerevisiae fermentation the colorant of heated red beet root extracts. African Journal of Biotechnology., 2013, 12, 728-34.

8. Shyamala, B. N.; Jamuna, P. Nutritional content and antioxidant properties of pulp waste from Daucus carota and Beta vulgaris. Malaysian Journal of Nutrition., 2010, 16, 114-21. 
9. Huda-Faujan, N.; Noriham, A.; Norrakish, A. S. Babji, A.S. Antioxidant activity of plant methanolic extracts containing phenolic compounds. African J. of Biotech., 2009, 8(3), 484-489.

10. Geckil, H.; Ates, B.; Durmaz, G.; Erdogan, S.; Yilmaz, I. Antioxidant, free radical scavenging and metal chelating characteristic of Propilis. American Journal of Biochemistry and Biotechnology., 2005, 1, 27-31.

11. Ahmad, I.; and Beg, A. J. Antimicrobial and phytochemical studies on 45 Indian medicinal plants against multidrug resistant human pathogens. J of Ethnopharmacology., 2001, 74, 111-123.

12. Dar, S.; Lawrence, R. S. Evaluation of antibacterial properties of fruit peel extracts of Citrus karna against human pathogens. Int J Pharm Bio Sci., 2015, 6(1), 261-266.

13. Andrews, J. M. Determination of minimum inhibitory concentrations. Journal of Antimicrobial Chemotherapy., 2014, 8(1), 5-16.

14. Rasooli, I.; Abyanek, M. R. Inhibitory effect of thyme oils on growth and aflotoxin production by Aspergillus parasiticus. Journal of Food Control., 2004, 15, 479-483.

15. Canadanovic-Brunet, J. M.; Savatovic, S. S.; Cetkovic, G. S.; Vulic, J. J.; Dililas, S. M.; Markov, S. L.; Cvetkovic, D. D. Antioxidant and antibacterial activities of Beet root Pomace extract. Czech Journal of Food Science., 2011, 29, 575-585.
16. Ruberto, G.; Baratta, M. T. Antioxidant activity of selected Essential oil components in two lipid model systems. Food Chemistry., 2000, 69, 167-174.

17. Kumar, S.; Brooks, M. S. Use of Red Beet (Beta vulgaris L.) for Antimicrobial Applications-a Critical Review. Food Bioprocess Technol., 2017, DOI 10.1007/s11947-017-1942-z

18. Chandrasekaran, M.; Kannathasan, K.; Venkatesalu, V. Antimicrobial Activity of Fatty Acid Methyl Esters of Some Members of Chenopodiaceae. Zeitschrift fur Naturforschung C., 2008, 331-336. DOI: 10.1515/znc-2008-5-604

19. Xu, Li.;Wang, G.; Shi, Y. Chemical constituents from Tagetes erecta flowers. Chemistry of Natural Compounds., 2011, 47(2), 281-283

20. Xing, Y.; Peng, H. Y.; Zhang, M.; Li, X.; Zeng, W. W.; Yang, X. Caffeic acid product from the highly copper-tolerant plant Elsholtzia splendenspost-phytoremediation: its extraction, purification, and identification. Journal of Zhejiang University (biomedicine \& biotechnology)., 2012, 13(6), 487-493.

21. Intekhab, J.; Aslam, M. Isolation of a flavonoid from Feronia limonia. Journal of Saudi Chemical Society., 2009, 13, 295-298

22. Li, Y. M.; Wang, T. Z.; Wang, Z. X. Studies on chemical constituents in dried buds of Lonicera similis Hemsl. Journal of Chinese Materia Medica., 2001, 26, 45-47. 